\title{
MONOTERPENES, SESQUITERPENES AND FATTY ACIDS FROM JULOCROTON TRIQUETER (EUPHORBIACEAE) FROM CEARA - BRAZIL
}

\author{
SIDNEY G. DE LIMA ${ }^{*}$, JOSÉ M. M. NETO ${ }^{1}$, ANTÔNIA M. G. LOPES CITO ${ }^{l}$ \\ JOSÉ G. M. DA COSTA2 FRANCISCO A. M. REIS ${ }^{3}$ \\ ${ }^{1 *}$ Departamento de Química, Universidade Federal do Piauí, Campus Universitário Ministro Petrônio Portella - Bairro Ininga - \\ Teresina - PI. CEP: 64.049-550. ${ }^{2} L P P N-U R C A$. Crato - CE, Brasil. \\ ${ }^{3}$ Instituto de Química - Unicamp - Campinas - SP. \\ (Received 21 April 2008 - Accepted 28 July 2008)
}

\begin{abstract}
In this study the volatile constituents from leaves and fruits of Julocroton triqueter (Lam.) Didr. (Euphorbiaceae), a medicinal plant from northwest Brazil, were investigated by GC/MS. Twenty one compounds, which represent about $96 \%$ of the total constituents of the essential oil, were identified. Caryophyllene oxide, humulene epoxide II, trans-caryophyllene, occidentalol, $\alpha$-humulene in the fruit and cis-carvyl acetate, spathulenol, cis-carveol, trans-caryophyllene, transcarvyl acetate and $\alpha$-humulene in the leaves were the principal components. From one fraction of the hexane extract of the fruits a mixture of fatty acids were identified as: dodecanoic, tetradecanoic, hexadecanoic, 9-octadecenoic, eicosanoic, trieicosanoic and tetracosanoic acids. The partial analysis of the non-volatile constituents (hexanic fraction) from fruit allowed the isolation and characterization of tetracosan-1-ol (identify by ${ }^{1} \mathrm{H}$ and ${ }^{13} \mathrm{C}$ NMR, FTIR).
\end{abstract}

Keywords: Julocroton triqueter, volatile constituents, Euphorbiaceae, fatty acid

\section{INTRODUCTION}

The Euphorbiaceae family presents about 7.500 species distributed mainly in tropical areas with larger dispersion centers in America and Africa ${ }^{1-2}$. It has great importance not only for the number of species but also for its economical implications related to medicinal and cosmetic industry as well as for its toxicological aspects ${ }^{3-6}$. Many Euphorbiaceae are well known in different parts of the world as toxic and/or medicinal. The high diversity of the described effects is a reflex of the high chemical diversity of this plant group ${ }^{3}$. The genus Julocroton (Euphorbiaceae) has many representative species in Brazil and some of them are widely used in the folk medicine to treat syphilis and ulcers - J. triqueter and depurative - J. humilis ${ }^{5}$.

The ethanolic and hydroalcoholic extract from $J$. triqueter has been evaluated and presented potential antileishmanial results, with $\mathrm{IC}_{50} 29.5 \mu \mathrm{g} \backslash$ $\mathrm{mL}^{7-9}$. Nakano et al..$^{10-11}$ and Anastasi ${ }^{12}$ reported the isolation and structural determination of the compound julocrotine in J. subpannosus, J. camporum and $J$. montevidensis ${ }^{13-14}$. Most of the species have not been studied from the chemical and pharmacological point of view, and the activity studied had been applied only to crude fixed extracts. In this work we report the partial chemical composition of essential oil from the leaves and fruit of J. triqueter (Lam.) Didr. The chemical composition of the hexanic extract and its methyl ester fraction were also investigated.

\section{MATERIALS AND METHODS}

\section{Plant material:}

The botanical material was collected at Sobral - Ceará - Brazil and the vegetable material and voucher specimen were deposited at Prisco Bezerra Herbarium, UFC, under the number 27652 , it was identified by L.W. LimaVerde.

\section{Volatile Constituent:}

Fresh leaves and fruit samples $(1.0 \mathrm{Kg})$, harvested at the State of Ceará, of Julocroton triqueter (Lam.) Didr. were subjected to hydrodistilation for 2 hours in a Clevenger-type apparatus. The isolated essential oils were dried over anhydrous sodium sulfate and, after filtration, maintained under refrigeration before analysis.

\section{NMR Spectra:}

NMR spectra were recorded on a Bruker 500 spectrometer (11.7 Tesla, $500 \mathrm{MHz}$ for ${ }^{1} \mathrm{H}$ and $125 \mathrm{MHz}$ for ${ }^{13} \mathrm{C}$ ), in $\mathrm{CDCl}_{3}$. Chemical shifts $\delta$ (in ppm) are given from internal TMS. The IR spectra were recorded on a Perkin Elmer - Model Spectrum 1000 FTIR $\left(\mathrm{KBr}, 4000 \mathrm{~cm}^{-1}\right.$ to $\left.400 \mathrm{~cm}^{-1}\right)$.

Gas chromatography/mass spectrometry:

Analysis of the oil was performed on HP (5890 A, II MSD) gas chromatograph, connected with MS system (HP 5971 A): dimethylsiloxane
DB-5 fused silica capillary column (30 m x $0.25 \mathrm{~mm}, 0.1 \mathrm{~m}$ film thickness); carrier gas: helium $9 \mathrm{~mL} / \mathrm{min}$; injector temperature $250{ }^{\circ} \mathrm{C}$; detector temperature $200{ }^{\circ} \mathrm{C}$; column temperature $50-180{ }^{\circ} \mathrm{C}$ at $4{ }^{\circ} \mathrm{C} / \mathrm{min}$, then $180-250{ }^{\circ} \mathrm{C}$ at 20 ${ }^{\circ} \mathrm{C} / \mathrm{min}$. Mass spectrometer operating conditions $70 \mathrm{eV}$ ionization energy. Identification of individual components was based on their mass spectral fragmentation using two computer library MS searches (Wiley Mass Spectral Database 229), retention indices and comparison with literature data ${ }^{15-18}$ Relative percentage amounts were calculated from the total area under the peaks by the software of the apparatus.

\section{Extraction and Isolation:}

Dried and powdered fruits $(2,8 \mathrm{Kg})$ of $J$. triqueter were extracted two times with hexane $(3.5 \mathrm{~L})$, followed by ethanol, at room temperature. After solvent evaporation under vacuum 14.1 of hexane and $22.0 \mathrm{~g}$ ethanolic extract were obtained, respectively. The ethanolic extract was then fractionated on a silica gel column with hexane, chloroform, ethyl acetate and methanol, gradient eluition, yielding 7.45, 6.90, 3.29 and $3.70 \mathrm{~g}$ of extract, respectively. During the process of eluition with hexane was observed the formation of a precipitate yellow, which was then washed in the cold light petroleum, yielding $80 \mathrm{mg}$ of an amorphous solid white. This solid, soluble in chloroform, showed a single component on TLC and analysis by ${ }^{1} \mathrm{H}$ and ${ }^{13} \mathrm{C}$ RMN indicated the tetracosan1 -ol as constituent.

The hexane fraction $(7.45 \mathrm{~g})$ was subjected to saponification followed by methylation reaction ${ }^{19-21}$, and the reaction was followed by thin-layer chromatography. The reaction mixture was purified by chromatography column and the solvent was then evaporated in a vacuum (unsaponifiable: 0.5 g; saponifiable: $5.49 \mathrm{~g}$ ). A small portion (saponifiable) of the crude reaction was analyzed in GC-MS.

\section{RESULTS AND DISCUSSION}

The identification of the essential oil components was accomplished by comparison of their GC-MS retention indices as well as their mass spectra with corresponding data of authentic compounds of components of reference oils. To minimize the standard deviation arising from employing a sole substance as internal standard, we decided to employ a retention index, namely, Kovat's Index obtained by use of a mixture of the essential oil with eight n-alkanes as internal standards. This approach greatly improved the identification, especially for those compounds with very similar fragmentation patterns. The oils were analyzed on mono and sesquiterpenes, the main components being caryophyllene oxide (41.8\%), humulene epoxide II $(8.7 \%)$, transcaryophyllene (8.2\%), occidentalol (7.4), $\alpha$-humulene (4.5\%) and para-cimene $(4.2 \%)$ in the fruit and cis-carvyl acetate $(44.6 \%)$, spathulenol $(12.1 \%)$, ciscarveol $(10.8 \%)$, trans-caryophyllene $(6.0 \%)$, trans-carvyl acetate $(5.5 \%)$ and $\alpha$-humulene $(2.9 \%)$ in the leaf, Table 1 . 
Table 1. Chemical composition of the essential oil, obtained from leaves and fruits of Julocroton triqueter (Euphorbiaceae).

\begin{tabular}{|c|c|c|c|c|c|}
\hline $\begin{array}{l}\text { Fruits of } \\
\text { J. triqueter }\end{array}$ & $\begin{array}{l}\text { Retention } \\
\text { Index }\end{array}$ & $\begin{array}{c}\text { Relative Area } \\
\text { (\%) }\end{array}$ & $\begin{array}{l}\text { Leaves of } \\
\text { J. triqueter }\end{array}$ & $\begin{array}{c}\text { Retention } \\
\text { Index }\end{array}$ & $\begin{array}{l}\text { Relative } \\
\text { Area (\%) }\end{array}$ \\
\hline$\alpha$-terpinene & 1016 & 2.33 & trans-pinocarvyl acetate & 1295 & 2.91 \\
\hline para-cymene & 1022 & 4.20 & linalool & 1092 & 2.06 \\
\hline limonene & 1028 & 2.43 & cis-carveol & 1225 & 10.77 \\
\hline trans-pinocarveol & 1136 & 1.84 & trans-carvyl acetate & 1336 & 5.51 \\
\hline trans-carvyl acetate & 1336 & 2.66 & cis-carvyl acetate & 1364 & 44.57 \\
\hline$\delta$-elemene & 1334 & 1.40 & ----------- & ----------- & ----------- \\
\hline$\beta$-patchoulene & 1380 & 1.06 & ----------- & ----------- & ----------- \\
\hline$\beta$-bourbonene & 1379 & 2.91 & $\beta$-bourbonene & 1379 & 5.16 \\
\hline$\beta$-elemene & 1386 & 1.86 & spathulenol & 1574 & 12.14 \\
\hline$E$-caryophylene & 1414 & 8.16 & $E$-caryophylene & 1414 & 6.06 \\
\hline$\alpha$-humulene & 1451 & 4.50 & $\alpha$-humulene & 1451 & 2.91 \\
\hline thujopsadiene & 1461 & 2.67 & ---------- & ---------- & --------- \\
\hline occidentalol & 1546 & 7.44 & ----------- & ----------- & ----------- \\
\hline caryophyllene oxide & 1579 & 41.80 & ----------- & ----------- & ----------- \\
\hline humulene epoxide II & 1603 & 8.67 & humulene epoxide II & 1603 & 4.27 \\
\hline$\alpha$-muurolol & 1639 & 2.59 & ----------- & ----------- & ----------- \\
\hline
\end{tabular}

The partial analysis of the non-volatile constituents (hexane fraction) from $J$. triqueter fruit allowed the isolation of a compound, obtained in the form of an amorphous solid, soluble in chloroform, with a melting point of 75.8 - 77.3 ${ }^{\circ} \mathrm{C}$ (literature $\left.{ }^{22}: 77-79{ }^{\circ} \mathrm{C}\right)$. The ${ }^{1} \mathrm{H}-\mathrm{NMR}\left(500 \mathrm{MHz}, \mathrm{CDCl}_{3}\right)$ spectrum of the compound showed signals in: $3.60 \mathrm{ppm}(\mathrm{t}, 2 \mathrm{H}, \mathrm{H}-1) ; 1.26 \mathrm{ppm}(\mathrm{s}, 42 \mathrm{H})$; $0,86 \mathrm{ppm}(\mathrm{t}, 3 \mathrm{H}, \mathrm{H}-24)$. The analysis of Gated - Decoupled ${ }^{13} \mathrm{C}$ NMR $(125$ $\mathrm{MHz}, \mathrm{CDCl}_{3}$ ) and ${ }^{13} \mathrm{C}$ NMR- DEPT $135^{\circ}$ spectrum allowed us to identify signals in: 32.9 ppm $\left(\mathrm{CH}_{2}, \mathrm{C}-2\right) ; 31.9 \mathrm{ppm}\left(\mathrm{CH}_{2}, \mathrm{C}-22\right) ; 29.4-29.7 \mathrm{ppm}(18$ $\left.\mathrm{CH}_{2}\right) ; 25.8 \mathrm{ppm}\left(\mathrm{CH}_{2}, \mathrm{C}-3\right) ; 22.7 \mathrm{ppm}\left(\mathrm{CH}_{2}, \mathrm{C}-23\right) ; 14.2 \mathrm{ppm}\left(\mathrm{CH}_{3}, \mathrm{C}-24\right)$ and $63,1 \mathrm{ppm}\left(-\mathrm{CH}_{2}-\mathrm{O}, \mathrm{C}-1\right)$. FT-IR spectrum showed important stretching and bending vibrations : $3342 \mathrm{~cm}^{-1}$ (O-H stretch); $2918 \mathrm{~cm}^{-1}$ and $2849 \mathrm{~cm}^{-1}\left(s p^{3} \mathrm{C}-\mathrm{H}\right.$ absorption); $1465 \mathrm{~cm}^{-1}$ (methylene groups bending absorptions); $1064 \mathrm{~cm}^{-1}$ (C-O, stretching vibration) and $725 \mathrm{~cm}^{-1}$ (bending motion associated with four or more $\mathrm{CH}_{2}$ groups in an open chain). The analysis of spectral data allowed us to identify the compound as the Tetracosan-1-ol.

The methylester analysis, obtained from the fatty material, lead to the identification of dodecanoic $(0.85 \%)$, tetradecanoic $(1.15 \%)$, hexadecanoic (26.92\%), 9-octadecenoic (19.36\%), eicosanoic $(6.0 \%)$, trieicosanoic $(2.29 \%)$ and tetracosanoic acid $(0.89 \%)$ as main constituents (Table 2).

Table 2. Composition of the main fatty acid detected in the fixed oil of Julocroton triqueter (Euphorbiaceae).

\begin{tabular}{|l|c|c|}
\hline \multicolumn{1}{|c|}{ Fatty acid } & $\begin{array}{c}\text { Retention } \\
\text { Time }\end{array}$ & $\begin{array}{c}\text { Relative } \\
\text { Area (\%) }\end{array}$ \\
\hline non identified & 11.06 & 5.77 \\
\hline dodecanoic acid (C12:0) or lauric acid & 12.51 & 0.85 \\
\hline tetradecanoic acid (C14:0) or myristic & 15.41 & 1.15 \\
\hline hexadecanoic acid (C16:0) or palmitic acid & 18.24 & 26.92 \\
\hline octadecanoic acid (C18:0) or stearyc acid & 19.67 & 1.60 \\
\hline 9-octadecenoic acid (C18:1) or oleic acid & 20.43 & 19.36 \\
\hline eicosanoic acid (C20:0) or araquidic acid & 23.10 & 6.07 \\
\hline trieicosanoic acid (C23:0) & 25.12 & 2.29 \\
\hline $\begin{array}{l}\text { tetracosanoic acid (C24:0) or lignoceric } \\
\text { acid }\end{array}$ & 27.12 & 0.89 \\
\hline \multicolumn{2}{|c|}{ Total fatty acids $=\mathbf{6 4 . 9 \%}$} \\
\hline
\end{tabular}

The results of this preliminary analysis shall be important from the pharmacological point of view, since components of the essential oil have been found to have powerful anti-inflammatory ( $\alpha$-humulene and caryophylene), anti-bacterial, anti-ulcer and anti-fungal (caryophylene and its oxide) and anti-septic (linalool) properties. It has been identified about $96 \%$ of the total constituents and in general the study showed that the essential oils present different chemical compositions in different parts of the plant, yielding ranges from 0.12 to $0.30 \%(\mathrm{w} / \mathrm{w})$ on fresh weight basis. The compounds trans-carvyl acetate, trans-caryophyllene, $\alpha$-humulene and humulene epoxide were found in essential oils from both leaves and fruits. Unfortunately, there is no other study on Julocroton oil in the literature for comparison purposes and because there is no available data on the biological activity, variability of the composition of essential oil content with regard to season, climate and age, the effects of these variables will be currently studied in our laboratory.

\section{ACKNOWLEDGMENTS}

We are thankful to Prof. Afrânio G. Fernandes from the Institute of Biology (UFC) for identifying the plant material, we are grateful to CAPES for financial support and research fellowships, CENAUREMN - UFC for the NMR usage.

\section{REFERENCES}

1. A. Branco, M. G. Pizzolatti, Quimica Nova. 25, 15, (2002).

2. J. C. Fuentes, V. Castro, J. Jakupovic, R. Murillo, Rev. Biol. Trop. 52, 269, (2004).

3. A. Salatino, M. L. F. Salatino, G. Negri, J. Braz. Chem. Soc. 18, 11, (2007).

4. E. R. Silveira, O. D. Loiola, Constituinte Micomoleculares de Plantas do Nordeste com Potencial Farmacológico: com dados de RMN ${ }^{13} \mathrm{C}$, Fortaleza - CE, Brasil: Expressão Gráfica e Editora, 216p, 2005.

5. S. G. De Lima, Contribuição ao Conhecimento Químico de Plantas do Nordeste do Brasil: Combretum laxum Jacq. (Combretaceae), Croton adenocalyx Baill (Euphorbiaceae) e Julocroton sp (Euphorbiaceae), Dissertação de Mestrado. Universidade Federal do Ceará - UFC, Fortaleza - CE, Brasil, 2000.

6. H. Lorenzi, F. J. A. Matos. Plantas Medicinais no Brasil: Nativas e Exóticas Cultivadas, Instituto Plantarum, Nova Odessa, 2002.

7. J. L. Bezerra, G. C. Costa, T. C. Lopes, I. C. D. S. Carvalho, F. J. Patrício, S. M. Sousa, F. M. M., Amaral, J. M. M. Rebelo, R. N. M. Guerra, Rev Bras Farmacogn. 16, 631, (2006). 
8. I. C. D. S. Carvalho, G. C. Costa, F. R. Nascimento, R. M. N. Guerra, M. N. S. Ribeiro, Estudos químicos e biológicos de Julocroton triqueter (LAm.) Didr. var. triqueter. In: XVIII Simpósio de plantas medicinais do Brasil, 2004, Manaus. In XVIII Simpósio de plantas medicinais do Brasil, 2004, p 398.

9. I. C. D. S. CARValho, G. C. COSta, R. N. M. GUERRA, F. R. Nascimento, M. N. S. RIBEIRO, Estudos químicos e biológicos de Julocroton triqueter (Lam.) Didr. var. triqueter. In: XVIII Simpósio de Plantas Medicinais do Brasil, 2005, Manaus. Anais, 2005.

10. T. Nakano, C. Djerassi, Anales Asoc. Quim. Arg. 303, (1962).

11. T. Nakano, O. O. Orazi, R. A. Corral, C. Djerassi, J. Org. Chem. 26, 1184, (1961).

12. C. Anastasi, Anales de la Asoc Quim Arg. 13, 348, (1925).

13. A. I. Suarez, Z. Blanco, F. Delle Monache, R. S. Compagnone, F. Arvelo, Nat Prod Res. 18, 421, (2004).

14. T. Konishi, M. Azuma, R. Itoga, S. Kiyosawa, Y. Shimada, Chem. Pharm. Bull., 44, 229, (1996).
15. N. Radulovic, E. Mananjarasoa, L. Harinantenaina, A. Yoshinori, Biochemical Systematic and Ecology. 34, 648, (2006).

16. R. P. Adams, Identification of Essential Oil Components by Gas Chromatography/Quadrupole Mass Spectroscopy. 4th Edition. Allured Publishing Corporation: Carol Stream, Illinois, USA, 2005.

17. M. Hadad, J. A. Zygadlo, B. Lima, M. Derita, G. E. Feresin S. A. Zacchino, A. Tapia, J. Chil. Chem. Soc. 52, 1186, (2007).

18. J. W. Alencar, A. A. Craveiro, F. J. A. Matos, J. Nat. Prod. 47, 890, (1984).

19. A. Nickavar, F. Mojab, K. Javidnia, M. A. R. Amoli, Z. Naturforsch . 58C, 929, (2003)

20. W. Esteves, L. A. G. Gonçalves, D. Barrera-Arellano, Metodologia Padrão Alemã para Análise de Gorduras e Outros Lipídios. $1^{\circ}$ Ed., Gráfica Vieira: Campinas, Vol. 1, 485p, 1995.

21. F. J. A. Matos, Introdução a Fitoquímica Experimental, $2^{\circ}$ Ed., Edições UFC: Fortaleza - CE, 141p, 1997.

22. D. C. Ayres, Dictionary of Natural Products. Chapman \& Hall. V.5, T-281, 1994. 